\title{
Anti-TWEAK Monoclonal Antibody RG7212
}

National Cancer Institute

\section{Source}

National Cancer Institute. Anti-TWEAK Monoclonal Antibody RG7212. NCI Thesaurus.

Code C97337.

A humanized monoclonal antibody directed ag ainst the apoptotic lig and TNF-like weak inducer of apoptosis (TWEAK) with potential antineoplastic activity. Anti-TWEAK monoclonal antibody RG7212 binds to TWEAK and prevents the binding of TWEAK to its receptor, FGF-inducible molecule 14 (Fn14), thereby blocking the TWEAK/Fn14 signaling. This may prevent tumor cell proliferation, invasion, migration and angiogenesis. TWEAK has pleiotropic effects, mediating proinflammatory and pro-angiogenic activity as well as stimulation of invasion, mig ration, and survival mediated via its receptor Fn14; Fn14 is expressed at relatively low levels in normal tissues, but is elevated in tumor cells and locally in injured and diseased tissues. 